\title{
ОСОБЛИВОСТІ ФОРМУВАННЯ ЕКОЛОГІЧНОЇ СВІДОМОСТІ ПІДЛІТКА ЗАСОБАМИ СОЦІАЛЬНИХ МЕДІА
}

\author{
Валерія Мошура \\ аспірантка кафедри політичної психології та міжнародних відносин \\ Національний педагогічний університет імені М. П. Драгоманова \\ 01601, Україна, м. Київ, вул. Пирогова, 9 \\ valeriamoshura@gmail.com, https://orcid.org/0000-0003-3721-3221
}

\section{Анотація}

В статті теоретично й емпірично досліджується вплив сучасних соціальних медіа на формування і розвиток екологічної свідомості підлітка. Розглянуто зміст понять «екологічна свідомість», «соціальні медіа», «екологічна криза». Виокремлено фактори, що впливають на якість публікацій у соціальних мереж і екологізацію соціальних мереж. Встановлено необхідність в екологізації сучасної медіа-освіти, іiі стійкому розвитку та оновленні у відповідності до вимог сьогодення суспільства і довкілля. Нами було проведено емпіричне дослідження екологічної свідомості, в якому взяли участь учні загальноосвітнього навчального закладу - Гончарівської гімназії Чернігівсього району, Чернігівської області (n=60). В дослідженні було використано такі методи дослідження: контент-аналіз, методика «ЕЗОП» та бланк «Натурафіл». Підібраний банк методик дозволив нам оцінити рівень розвитку екологічної свідомості особистості школяра, що допоможе виокремити пріоритетні напрямки роботи з ними в медіапросторі. За результатами проведеного дослідження та за допомогою контент-аналізу соціальних мереж підлітків, що дало змогу виокремити основну проблематику у взаємодії людини і природи, встановлено, що в середньому близько 18\% обстежуваних продемонстрували низький рівень розвитку екологічної свідомості, що характеризується зневажливим і споживчим ставленням дитини до природи. Близько 35\% мають найбільш сформоване естетичне й прагматичне ставлення до природи, інакше кажучи, вони сприймають їі як «красиву та корисну». Лише 16\% респондентів мають задовільний рівень екологічної свідомості, що характеризується тим, що підліток сприймає природу як джерело знань і майбутнього. Перспективи подальших досліджень вбачаємо у теоретичному та емпіричному вивченні стану розвитку екологічної свідомості у підлітків і можливих шляхів його покращення.

Ключові слова: екологічна свідомість, медіа-освіта, підлітковий вік, екологічна освіта, екологічна криза, екологічна компетентність.

\section{Вступ}

В наш час, коли глобальна екологічна криза $є$ однією із найбільших загроз, а іiі попередження - найважливішим завданням для сучасності, в усьому світі велика увага приділяється проблемі екологічної свідомості людини (Андрєєв, 2009). На сучасному етапі розвитку в Україні відбувається активна інформатизація багатьох сфер життя та діяльності людини: обмін інформацією набув миттєвого та універсального характеру; значно зросли й продовжують зростати варіанти збору, обробки, зберігання, передачі інформації та безпосереднього доступу до неї; безпрецедентно зросла кількість персональних i 
корпоративних контактів на локальному і глобальному рівнях (Гірусов, 1983). Впровадження інформаційних і онлайн-технологій також інтенсивно відбувається в сучасній психологічній діяльності.

Наразі, соціальні мережі стали одним із провідних шляхів обміну інформацією, новинами, засобом комунікації. В підлітковому віці вплив соціальних мереж на розвиток особистості загалом особливо помітний: інфлюенція блогерів, веб-спільнот тощо. Для сучасного покоління соцмережі стали невід'ємною частиною повсякденного життя, що може і має стати рушієм для пропаганди активного розвитку екологічної свідомості. Основними завданнями соціальних мереж у розвитку екологічної свідомості підлітка мають стати такі: сформувати сприйняття того, що людина є вищою цінністю і є невід'ємною частиною природи і має співіснувати взаємовигідно, без шкоди одне одному, показати приклад реалізації екологічної доцільності діяльності людини в навколишньому середовищі.

Екологічна свідомість - мультидисциплінарна категорія. Теоретико-методологічні засади екологічної свідомості розроблялися у філософії (Р. Біджиєва, І. Гоношиліна, Є. Громов, К. Каландаров та ін.), антропології (Г. Бейтсон, С. Хорунжий та ін.), соціології (Дж. Маркович, В. Жуков та ін.), соціальній психології (Г. Акопов, А. Алдашека, В. Медведєв, В. Скребець, Є. Чермидова та ін.), екологічній психології (Дж. Дж. Гібсон, Р. Баркер, В. Глєбов, С. Дерябо, О. Калмиков, Ю. Ковтун, М. Мдівані, К. Павлік, В. Панов, К. Стапф, О. Стерлігова, В. Ясвін та ін.)

Так, розвитком екологічної свідомості в своїх роботах займалися такі вчені, як: Р. Біджиєва, Г. Бейтсон, А. Валітова, Е. Гірусова, Т. Іванова, Т. Казначеєва, А. Кочергіна, В. Пустовойтова, В. Сітарова, Л. Яо та ін. Розробкою теоретичних основ екологічної свідомості, як питання розвитку суспільства, займалися вчені: В. Вернадський, М. Моїсеєв, А. Урсул та ін. Аналіз проблеми взаємин із довкіллям, розвитком соціуму, ціннісних орієнтацій суспільства здійснено такими вченими, як: Г. Бачинський, Б. Бессонов, В. БгандаЦерера, А. Єрмоленко, М. Кисельов, В. Лозовий, В. Лось, В. Лисенкова, В. Хесле та ін. Безпосередньо проблему екологічної свідомості в межах екологічної психології вивчали російські (А. Адаменко, І. Кряж, Л. Макарова, В. Медвєдєв, Н. Мухамбетов, Т. Носова, О. Павлова, В. Панов, Д. Петяєва, В. Ясвін та ін.) та українські (О. Гарнець, О. Вернік, О. Килимник, А. Льовочкіна, Д. Отич, М. Романова, О. Рудоміно-Дусятська, В. Скребець, І. Сяська, Ю. Шайгородський, Ю. Швалб та ін.) психологи.

Питанням формування свідомості та самосвідомості підлітка займалися такі вчені, як: К. Абульханова, М. Боришевський, В. Столін, Л. Рубінштейн, Т. Титаренко, П. Чамата та ін. Вплив медіа на розвиток свідомості людини вивчали такі вчені, як: О. Баришполець, О. Вознесенська, О. Голубєва, Л. Зайко, В. Карлова, Г. Мюнстенберг, Г. Мироненко, Л. Найдьонова, Н. Обухова, В. Степанов, Г. Олпорт, Н. Череповська та ін.

Всі ці дослідження дали широке коло розумінь і дефініцій феномена «екологічна свідомість». Зокрема, за визначенням В. Скребець, «екологічна свідомість - це вищий рівень психічного відображення природного і штучного середовища, свого внутрішнього світу, рефлексія місця і ролі людини в біологічному, фізичному i хімічному світі, а також саморегуляція цього відображення» (Скребець, 2006, 25).

Найважливішими елементами екологічної свідомості за класифікацією Л. Лисенко (Лисенко, 2013) є усвідомлення:

- обмеженості природи, інтегральною частиною якої є людина; 
- необхідності відмови від домінування людини над природою i необхідності встановлення динамічної рівноваги між природними системами і людською системою;

- екологічної кризи як суспільної кризи;

- глобального характеру екологічної кризи;

- необхідності вирішення екологічної кризи;

- необхідності розробки глобальної стратегії розвитку як передумови існування життя;

- існування екосвідомих соціальних сил, їх до готовності продуктивного спілкування та здатності до передбачення спрямування і динаміки розвитку суспільства.

Екологічна свідомість більшості людей складається стихійно. Щоб структурувати цей процес, потрібне залучення наукових, ідеологічно інтерпретованих знань. Важливо пам'ятати про той факт, що становлення екологічної свідомості є процесом переорієнтації формування активної позиції та означає не просто дбайливе ставлення людини до природи, а й свідому екологічну діяльність (Євдокимова, 2007). Щоб екологічні переконання стали реальними двигунами поведінки людей, вони мають досягти певного рівня зрілості й цілеспрямованості (Barker, 1968).

Як засвідчив порівняльний аналіз наукових джерел, найбільш сенситивним для формування настанов екологічного ставлення до себе та світу є підлітковий вік. Таке ставлення формується через отримання інформації, освіту, самоосвіту та спілкування. Одним із шляхів отримання знань у сучасному світі для підлітка (навіть більшою мірою, ніж для дорослої людини) є мережа Інтернет, інтерактивне спілкування в соціальних мережах, дописи в групах тощо.

В умовах світової пандемії COVID-19 та загальної діджиталізації формальної, неформальної та інформальної освіти, для успішного формування екологічної свідомості підлітка засобами медіа-освіти освітян і практичних психологів мають вирізняти:

1) високий рівень комунікативної компетентності - це надає можливості вільно налагодити контакт 3 підлітком, чітко і у повній мірі будувати свою думку і спілкуватися на «його мові»;

2) організаторські здібності - дозволяють психологу побудувати процес взаємодії $з$ підлітком, пояснити йому основні аспекти екологічної взаємодії 3 навколишнім середовищем, створити дієву структуру занять та впливати на подальшу роботу 3 формування екологічної свідомості;

3) здатність до рефлексії - допомагає психологу відслідковувати стан підлітка, аналізувати ситуації, що складаються у процесі роботи;

4) гнучкість поведінки - дозволяє практичному психологу швидко реагувати на ситуації, які складаються у процесі взаємодії з підлітком;

5) креативні здібності психолога - сприяють перетворенню медіа-освітніх занять 3 формування екологічної свідомості на цікавий і творчий процес, застосовуючи нові форми взаємодії з підлітками, знаходити компроміси і вирішувати складні, екстрені ситуації у разі необхідності (Пономаренко, 2020).

Водночас у вітчизняній науці проблема впровадження медіа-освіти у процесі розвитку і формування екологічної свідомості підлітка не знайшла належного науково-теоретичного i практичного обгрунтування, відповідного методичного забезпечення. Неформалізований контент-аналіз форумів, інтернет-сайтів, інтернет-конференцій, соціальних мереж щодо питання екологічної грамотності та екологічної свідомості людини засвідчує, що частина 
психологів недостатньо готові до використання сервісів мережі інтернет для професійнопсихологічної взаємодії, зокрема пропагування здорового ставлення особистості до екології, консультування та розвитку екологічної свідомості клієнта, організації проєктної діяльності. Вподобання психологів, які володіють інтернет-технологіями, надаються, переважно пошуку і отриманню інформації. Невисока активність, психологів, неякісний контент, інтернетнеграмотність на форумах і чатах, тобто психологічний потенціал інформаційної взаємодії за допомогою мережі інтернет залишається незатребуваним, що значно знижує ефективність застосування дистанційних технологій.

Активний неформальний розвиток екологічних уявлень за допомогою засобів масової інформації, інтернет-видань, соціальних мереж тощо потребує нових досліджень у цій галузі. Отже, незважаючи на велику кількість досліджень екологічної свідомості, тема формування екологічної свідомості підлітка засобами соціальних медіа не є достатньо вивченою, що спонукало до вибору теми статті.

Мета статті полягає у теоретичному та емпіричному дослідженні екологічної свідомості підлітка засобами сучасної медіа-освіти. Завдання дослідження: 1) визначити сутність та особливості впливу медіа-освіти на розвиток екологічної свідомості підлітка; 2) здійснити аналіз проблеми розвитку екологічної свідомості в підлітковому віці.

\section{Методи дослідження}

Емпіричне дослідження було проведене у період з жовтня по грудень 2019 року. В дослідженні взяли участь 60 учнів 6-7 класів Гончарівської гімназії Чернігівського району Чернігівської області. Підібраний банк методик дозволив оцінити рівень екологічної свідомості суб'єктивного ставлення до природи. За допомогою контент-аналізу ми дослідили матеріали соціальних мереж, спільнот, інтернет-ресурсів на тему екології та зацікавленість нею підлітків.

Передусім завдання контент-аналізу в дослідженні масової екологічної свідомості полягало в установленні таких аспектів:

1. Виокремити поняття, що згадуються, в контексті екологічної теми.

2. Виявити частоту й обсяг даних згадувань.

3. Провести порівняльний аналіз змін впродовж дослідження.

Одиниці аналізу - це фрагменти тексту, за допомогою яких можна знайти посилання на певні категорії або їх виражені ознаки в тексті. Одиниці, залежно від цілей аналізу, типу інформаційного масиву, а також ряду додаткових факторів можуть бути досить різними. Класифікатор контент-аналізу обраних тем публікацій у соціальній мережі Інстаграм поділили на такі категоріі:

1) флора і фауна (рослини, тварини, птахи, риба, ссавці, кущі, дерева, трава, комахи, ліс, посадки, поля);

2) земля (чорнозем, корисні копалини, каміння, грунт, піски);

3) забруднення (Чорнобиль, атмосфера, забруднення, викиди, стічні води);

4) шкідливі дії (лісові пожежі, браконьєрство, вирубування лісів, ліси Карпат, шкідливі дії).

Порівняльний аналіз висвітлення тем флори й фауни, землі, має спадні тенденції до 2019 року, але теми забруднення й шкідливих дій, натомість, за цей час набувають дедалі більшої актуальності. 
Варто зазначити, що контент-аналіз спрямований на встановлення саме когнітивного компонента свідомості, оскільки презентує основні об'єкти природного середовища, що потрапляють до уваги підлітків. За допомогою анкети «ЕЗОП» вивчено тип домінуючої установки щодо природи. За допомогою методики «Натурафіл» визначено рівень розвитку інтенсивності суб'єктивного ставлення підлітків до природи.

\section{Результати та дискусії}

При проведенні контент-аналізу було досліджено публікації спільнот та публікації на сторінках респондентів у соціальних мережах Instagram та Facebook та статті на сайтах, котрі учні використовують найчастіше для пошуку інформації, загальною кількістю близько 230. Сформовано провідні теми/категорії (у порядку їх згадування) та приклади слів із текстів, що до них належать:

1. Категорія «флора й фауна»: рослини, тварини, птахи, риба, ссавці, кущі, дерева, трава, комахи, ліс, посадки, поля тощо.

2. Категорія «забруднення»: Чорнобиль, атмосфера, забруднення, викиди, стічні води тощо.

3. Категорія «земля чорнозем, корисні копалини, каміння, грунт, піски та інші.

4. Категорія «шкідливі дії»: лісові пожежі, браконьєрство, вирубування лісів, ліси Карпат, шкідливі дії.

За результатами контент-аналізу з'ясовано, що найбільш популярною є категорія «флора і фауна» - 34,7\% від загальної кількості тематичних публікацій (80 згадувань), 25,2\% - категорія «забруднення» (58 публікацій), 21,7\% - згадувань категорії «земля» (50 згадувань) та 18,3\% - категорія «шкідливі дії» (42 публікації) (див. табл. 1).

Таблиия 1

\section{Результати контент-аналізу по категоріям}

\begin{tabular}{|c|l|c|c|}
\hline № & \multicolumn{1}{|c|}{ Категорія } & Кількість згадувань & Відсоток \\
\hline 1 & Флора і фауна & 80 & $34,7 \%$ \\
\hline 2 & Забруднення & 58 & $25,2 \%$ \\
\hline 3 & Земля & 50 & $21,7 \%$ \\
\hline 4 & Шкідливі дії & 42 & $18,3 \%$ \\
\hline
\end{tabular}

Отже, контент-аналіз публікацій в Instagram на екологічну тематику засвідчив значну кількість публікацій, зміст яких становить тема екології, проте цей контент не $є$ якісним 3 точки зору формування високого рівня екологічної свідомості підлітка, що підтверджує той факт, що необхідно покращувати та збільшувати контент у тематичних спільнотах і сайтах. Найбільше згадувань у публікаціях стосується флори й фауни, забруднення, шкідливих дій.

Зважаючи на результати контент-аналізу сучасного стану соціальних мереж i дослідження Т. Кулик (Кулик, 2013), виокремимо чотири функції екологічної свідомості в розвитку підлітків:

1) інформаційна: створює для аудиторії дані про актуальний стан довкілля, надання інформації про можливі ризики для людства та екосистем;

2) просвітнищька: надати інформацію для аудиторії про основні закони природи, та можливими наслідками і небезпеками антропогенної діяльності для навколишнього середовища; 
3) організаціийна: залучення читачів до прийняття рішень;

4) контролююча: шляхом інформування користувачів мережі про діяльність тих чи інших галузей діяльності, соціальні мережі допомагають у реалізації прав на інформацію про стан довкілля та на безпечні умови існування.

Для емпіричного дослідження було вибрано методику «ЕЗОП», котра визначає рівні домінування настанов щодо навколишнього середовища, та методику «Натурафіл», що допомагає у вивченні суб'єктивного ставлення до природи у підлітків. Ці методики було обрано для можливості діагностики ступенів сформованості екологічної свідомості учнів, що дасть змогу на подальшу розробку рекомендацій для практичних психологів, що працюють 3 підлітками в умовах сучасної медіа-освіти.

В результаті тестування за методикою «ЕЗОП» було встановлено, що у підлітків домінує естетична настанова (природа як об’єкт краси), яка спрямовує їх на естетичне задоволення природою, захопленням iï красою. На другому місці - прагматична настанова (природа як об’єкт використання), що орієнтує молодь на споживацьке використання природних ресурсів. Третє місце посідає когнітивна настанова (природа як об'єкт отримання знань), що, швидше за все, є наслідком провідної діяльності віку - навчанням. Найменшу кількість отримала етична настанова (природа як об'єкт охорони), що характеризується спрямованістю молоді на збереження екологічного середовища (рис. 1).

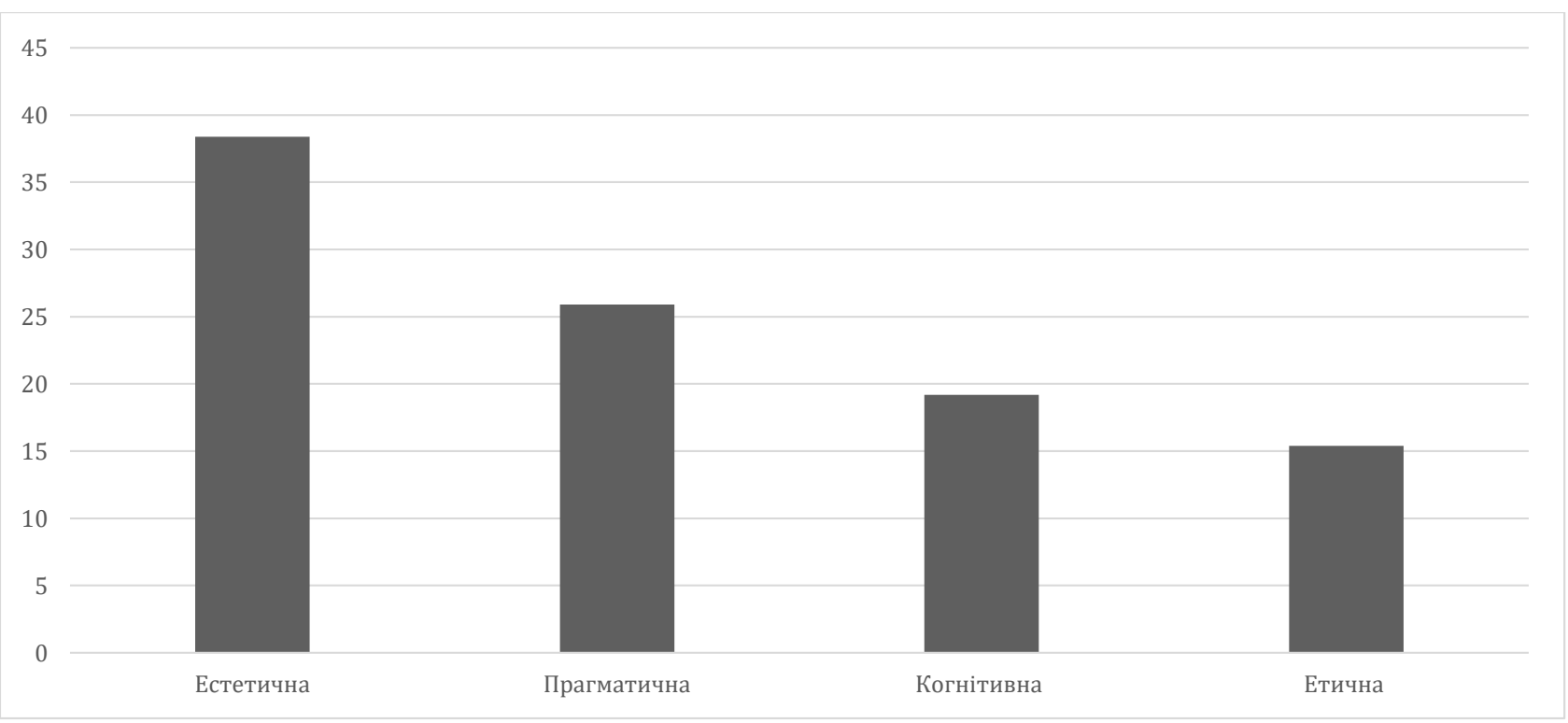

Рис. 1. Результати дослідження за методикою «ЕЗОП»

За результатами вивчення проблеми розвитку екологічної свідомості, підтверджено доцільність глибшого дослідження екологічної свідомості підлітків у сукупності іiі структурних і функціональних особливостей, індивідуальної екологічної свідомості. Це надасть базу для розробки оптимальної програми розвитку екологічної свідомості так, щоб змінити практичний тип мотивації, оптимізувати безпосереднє практичне використання природних об'єктів для задоволення харчових, технологічних й інших потреб людини, а також сприяти розумінню того, що навколишній світ потребує постійного піклування і що за його благополуччя кожен відповідає персонально. 
Методика «Натурафіл» призначена для діагностики рівнів розвитку суб'єктивного ставлення підлітків до природи. Під зазначеним вище ми розуміємо, в яких саме видах діяльності й на скільки інтенсивно виявляється ставлення. Методика містить чотири основні шкали, які відповідають чотирьом типам ставлення до природи: перцептивно-афективному, когнітивному, практичному i поступливому, а також додаткову шкалу натуралістичної обізнаності. Результати, одержані за методикою «Натурафіл», подано на рис. 2.

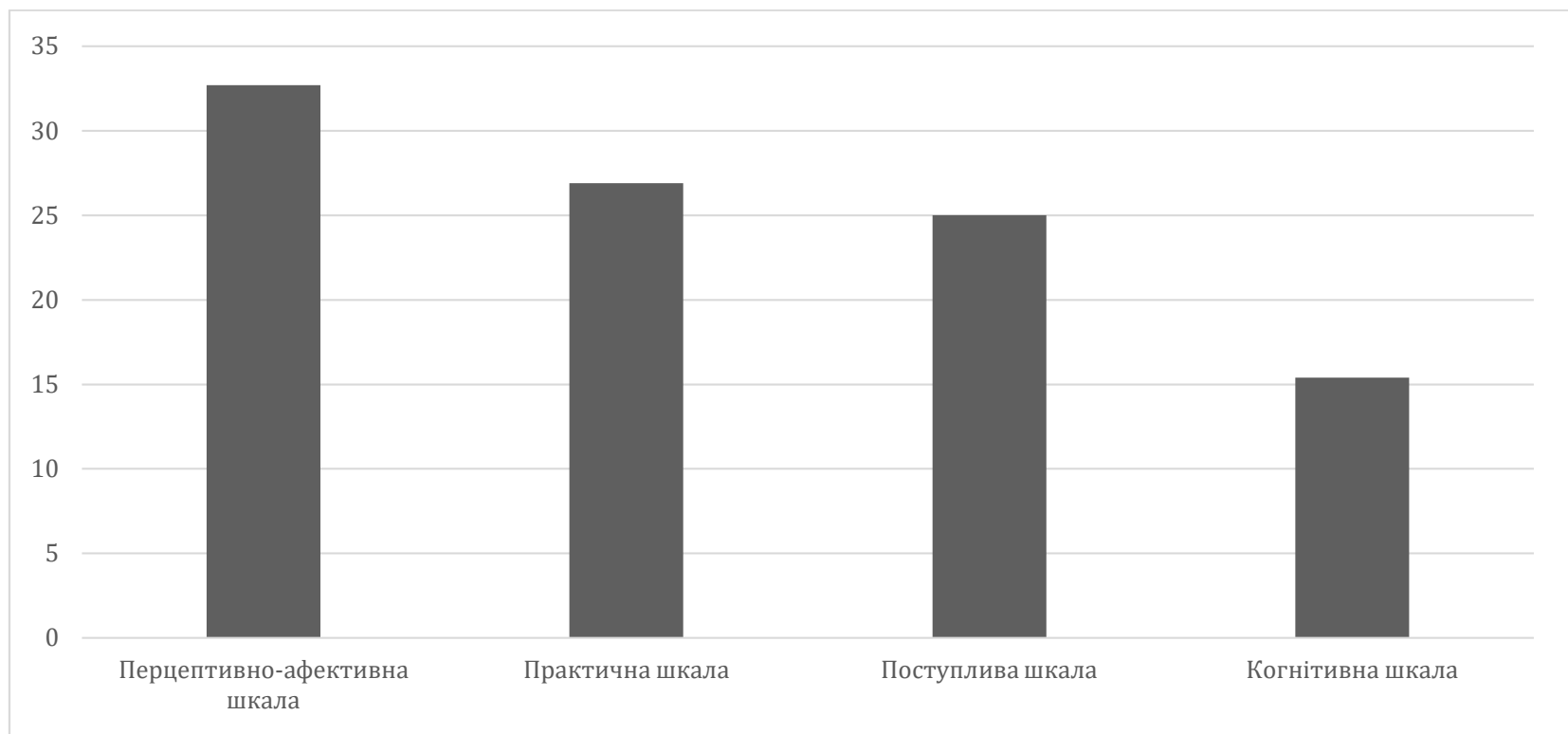

Рис. 2. Результати за методикою «Натурафіл»

Аналіз результатів дослідження засвідчує домінування естетичного освоєння об'єктів природи; з різницею лише у 5,8\% - практична шкала (практична взаємодія 3 об'єктами природи), наступна поступлива (зміна оточення), за нею шкала натуралістичної ерудиції (сукупність відомостей про об'єкти природи), остання - когнітивна шкала (пізнавальна активність). Таке зіставлення показників свідчить про те, що у підлітків найбільш сформоване естетичне й прагматичне ставлення до природи, інакше кажучи, вони сприймають іiі як «красиву та корисну». Природа для них є не лише джерелом отримання естетичної насолоди, а й джерелом задоволення своїх власних потреб. Отримані результати підтверджують доцільність глибшого дослідження екологічної свідомості школярів у сукупності іiі системно-структурних і системно-функціональних особливостей, індивідуальної й масової форм екологічної свідомості.

Отже, зважаючи на результати емпіричного дослідження, зазначимо, що екологічна свідомість сформована на високому рівні лише у 15,4\% респондентів. Це свідчить про необхідність впровадження нових методів іï розвитку серед підлітків. 37\% досліджуваних сприймають природу лише як предмет краси, а 26,9\% мають споживацьке ставлення до навколишнього середовища. Вплив соціальних мереж на розвиток екологічної свідомості підлітка може мати позитивну динаміку за умови якісного контенту, який отримує школяр, адекватного сприйняття з боку автора відповідальності за матеріал, що публікується. Адже підлітковий період - період активного здобуття та засвоєння знань, використання соціальних мереж для особистого використання і навчання, оскільки сьогодення дає змогу отримувати інформацію через мережу Інтернет, а не лише з друкованих видань. 


\section{Висновки}

В результаті проведеного дослідження нами було проаналізовано різні підходи до змісту поняття «екологічна свідомість», розглянуто структуру та шляхи іiі формування у особистості, зокрема в підлітків. При емпіричному дослідженні рівнів розвитку екологічної свідомості у підлітків, встановлено, що більшість мають низький рівень сформованості екологічної свідомості. Припускаємо, що це може бути пов'язано з відсутністю необхідної освітньо-виховної й тренінгової роботи, дисциплін і спецкурсів, які б сприяли формуванню і розвитку відповідних знань умінь і навичок щодо бережного ставлення до природи у підлітків, які мають бути сформовані ще в дошкільному віці. Зважаючи на популярність соціальних медіа серед населення, відзначимо, що розвиток екологічної свідомості неможливий без залучення медіа: для дітей - мультфільми екологічного змісту, цифрові рольові ігри; для підлітків: соціальні мережі (Інстаграм, Фейсбук і т. ін.), серіали, ігриаркади, для дорослих - інформаційні сайти, соціальні мережі, сайти новин тощо. Всі ці сервіси є рушієм формування тих чи інших складових екологічної свідомості особистості, проте вплив медіа зазвичай залишається поза межами системної виховної роботи 3 формування екологічної свідомості.

Отже, відзначимо, що розвивати екологічну свідомість сучасного підлітка, котрий здебільшого засвоює інформацію з соціальних медіа некритично і безсистемно, можливо лише за умови комплексного впливу. Цей вплив на екологічні уявлення людини та на екологічну свідомість впродовж усього її становлення та розвитку як особистості, з одного боку, поєднує усталені форми та підходи: фенологічну роботу, спостереження, бесіди, лекції, психологічні тренінги, а, з другого - сучасні формати: вебінари, майстер-класи, онлайнтренінги та онлайн-марафони, психологічні онлайн-квести та онлайн-конференції, прямі ефіри й stories в Facebook чи Instagram, інформаційно-мотиваційні відео у YouTube, Telegram-каналах та молодіжній мережі TikTok тощо. Саме грамотна інтеграція традиційних i сучасних методів психолого-педагогічного впливу сприятиме формуванню компетентності самостійної пізнавальної активності в підлітка, що дозволить йому свідомо отримувати та осмислювати інформацію екологічного спрямування з соціальних медіа та інших джерел. Це засвідчує, що сформовані, на належному рівні, екологічна свідомість та екологічні уявлення підлітків допоможуть їм проаналізувати фактори, які зумовили сучасне відчуження між природою й суспільством та загострення екологічної кризи на планеті.

Перспективи подальших розвідок вбачаємо в психодіагностиці екологічних уявлень особистості, експериментальному дослідженні ефективності психологічного тренінгу як форми оптимізації процесів екологічного самоусвідомлення, а також у розробці методичних рекомендацій із розвитку екологічних уявлень підлітків засобами соціальних медіа.

\section{Література}

1. Андрєєв, А.С. (2009). Психологічні аспекти екологічних проблем й екопсихологічні тренінги. Екологічна психологія: Збірник наукових праџзь інституту психологї ім. Г.С. Костюка АПН Украӥни, 7(19), 18-23.

2. Гирусов, Э.В. (1983). Экологическое сознание как условие оптимизации общества и природы. Философские проблемы глобальной экологии, 145-153.

3. Свдокимова, Т.О. (2007). Розвиток екологічної свідомості підлітків - учасників скаутського руху. (Дис. канд. псих. наук). Київ. 
4. Кулик, Т.М. (2013). Системно-динамічні особливості розвитку екологічної свідомості студентів. (Дис. канд. псих. наук). Луцьк.

5. Лисенко, Т.М. (2013). Особливості екологічної свідомості у студентів. Вісник Харківського начіонального педагогічного університету імені Г.С. Сковороди. Психологія, 46(1), 102-108.

6. Пономаренко, Т. (2019). Особливості побудови зворотного зв'язку в онлайн комунікації психолога при груповій взаємодії. Науковий часопис НПУ імені М.П. Драгоманова. Серія № 12. Психологічні науки, 8(53), 66-75.

7. Скребець, В.О. (2006). Екологічна свідомість: визначення поняття змісту і форм прояву. Екологічна психологія. Київ : Стакер.

8. Barker, R.G. (1968). Ecological psychology: Concept and methods for studying the environment of human behavior. Stanford, Calif. : Stanford University Press.

\section{References}

1. Andrieiev, A.S. (2009). Psykholohichni aspekty ekolohichnykh problem y ekopsykholohichni treninhy [Psychological aspects of ecological problems and ecopsychological trainings]. Ekolohichna psykholohiia: Zbirnyk naukovykh prats instytutu psykholohii im. H.S. Kostiuka APN Ukrainy - Environmental psychology: Collection of scientific works of the Institute of Psychology. G.S. Kostyuk, Academy of Pedagogical Sciences of Ukraine, 7(19), 18-23 [in Ukrainian].

2. Girusov, Je.V. (1983). Jekologicheskoe soznanie kak uslovie optimizacii obshhestva i prirody [Environmental awareness as a condition for optimizing society and nature]. Filosofskie problemy global'noj jekologii - Philosophical problems of global ecology, 145-153 [in Russian].

3. Yevdokymova, T.O. (2007). Rozvytok ekolohichnoi svidomosti pidlitkiv - uchasnykiv skautskoho rukhu [Development of ecological consciousness of teenagers - participants of the scout movement]. Candidate's thesis. Kyiv [in Ukrainian].

4. Kulyk, T.M. (2013). Systemno-dynamichni osoblyvosti rozvytku ekolohichnoi svidomosti studentiv [System-dynamic features of development of ecological consciousness of students]. Candidate's thesis. Lutsk [in Ukrainian].

5. Lysenko, T.M. (2013). Osoblyvosti ekolohichnoi svidomosti u studentiv [Features of ecological consciousness in students]. Visnyk Kharkivskoho natsionalnoho pedahohichnoho universytetu imeni H. S. Skovorody. Psykholohiia - Bulletin of Kharkiv National Pedagogical University named after G.S. Skovoroda. Psychology, 46(1), 102-108 [in Ukrainian].

6. Ponomarenko, T. (2019). Osoblyvosti pobudovy zvorotnoho zviazku v onlain komunikatsii psykholoha pry hrupovii vzaiemodii [Features of feedback in online communication of a psychologist in group interaction]. Naukovyi chasopys NPU imeni M.P. Drahomanova. Seriia № 12. Psykholohichni nauky - Scientific Journal of National Pedagogical Dragomanov University. Series 12. Psychological Sciences, 8(53), 66-75 [in Ukrainian].

7. Skrebets, V.O. (2006). Ekolohichna svidomist: vyznachennia poniattia zmistu i form proiavu. Ekolohichna psykholohiia [Ecological consciousness: definition of the concept of content and forms of manifestation. Environmental psychology]. Kyiv : Staker [in Ukrainian].

8. Barker, R.G. (1968). Ecological psychology: Concept and methods for studying the environment of human behavior. Stanford, Calif. : Stanford University Press. 


\title{
FEATURES OF ENVIRONMENTAL CONSCIOUSNESS FORMATION OF THE ADOLESCENTS BY MEANS OF SOCIAL MEDIA Valeriia Moshura \\ Postgraduate Student of the Department of Political Psychology and Social Legal Technologies \\ National Pedagogical Dragomanov University \\ 9, Pyrogov Str., Kyiv, Ukraine, 01601 \\ valeriamoshura@gmail.com, https://orcid.org/0000-0003-3721-3221
}

\begin{abstract}
The article investigates the influence of modern social media on the formation and development of environmental consciousness of adolescents from both the theoretical and empirical points of view. The article considers the content of the concepts of ecological consciousness, social media and ecological crisis. The factors influencing the quality of publications and social network "greening" are highlighted. The article has revealed the necessity of modern media education "greening", its sustainable development and renewal in accordance with the requirements of today's society and the environment. We conducted an empirical study of the environmental consciousness among the students of secondary school in Goncharivska gymnasium of Chernihiv district, Chernihiv region $(n=60)$. In the study, we used the following research methods: content analysis, "EZOP" method and the form "Naturafil". The selected bank of methods allowed us to assess the development level of environmental awareness of the student's personality that will help identify the priority areas of work with them in media space. According to the results of the study and the content analysis of social networks for adolescents that allowed to identify the main issues of the "man - nature" interaction, we found out that, on average, about $18 \%$ of respondents showed a low level of environmental awareness that is characterized by contemptuous and consumer attitude of the child to nature. About $35 \%$ of respondents have the most developed aesthetic and pragmatic attitude to nature, in other words, they perceive it as "beautiful and useful". Only $16 \%$ of respondents have a satisfactory level of environmental awareness, which is characterized by the fact that the adolescent perceives nature as the source of knowledge and future. Within the results obtained it is possible to outline the prospect of further study in the direction of theoretical and empirical research of the state of ecological consciousness development in adolescents and possible ways to improve it.
\end{abstract}

Keywords: ecological consciousness, media education, adolescence, ecological education, ecological crisis, ecological competence. 